\title{
Use of genetic mark-recapture to estimate breeding site fidelity and philopatry in a threatened sea duck population, Alaska-breeding Steller's eiders
}

\author{
David E. Safine ${ }^{1, *}$, Mark S. Lindberg ${ }^{2}$, Kate H. Martin ${ }^{3}$, Sandra L. Talbot ${ }^{4}$, \\ Ted R. Swem ${ }^{3}$, John M. Pearce ${ }^{4}$, Neesha C. Stellrecht ${ }^{3}$, George K. Sage ${ }^{4}$, \\ Ann E. Riddle ${ }^{5}$, Krystal Fales ${ }^{4}$, Tuula E. Hollmén ${ }^{5,6}$ \\ ${ }^{1}$ Division of Migratory Bird Management, US Fish and Wildlife Service, Anchorage, AK 99503, USA \\ ${ }^{2}$ Institute of Arctic Biology, University of Alaska Fairbanks, Fairbanks, AK 99775, USA \\ ${ }^{3}$ Fairbanks Fish and Wildlife Field Office, US Fish and Wildlife Service, Fairbanks, AK 99701, USA \\ ${ }^{4}$ Alaska Science Center, US Geological Survey, Anchorage, AK 99508, USA \\ ${ }^{5}$ Alaska SeaLife Center, Seward, AK 99664, USA \\ ${ }^{6}$ College of Fisheries and Ocean Sciences, University of Alaska Fairbanks, Fairbanks, AK 99775, USA
}

\begin{abstract}
The Steller's eider Polysticta stelleri is a sea duck that breeds in Arctic tundra regions of Russia and Alaska (USA). The Alaska-breeding population is listed as 'threatened' under the US Endangered Species Act because of a perceived contraction of the breeding range in North America. Understanding demography of the listed population is critical for evaluating measures that can lead to increased abundance and thus, long-term viability. Specifically, estimates of return rates to breeding areas by adult females and natal areas by juvenile females are needed for planning effective recovery actions. We used a suite of polymorphic loci to genotype individuals and generated genetic profiles of nesting females and female offspring from nest materials collected between 1995 and 2016 in a $\sim 170 \mathrm{~km}^{2}$ study area near Utqiag்vik, Alaska. We analyzed capture histories of genetically identified individuals to estimate breeding site fidelity, temporary emigration, and philopatry. From a sample of 365 nests, we found that breeding site fidelity of adult females was high $(0.91 \pm 0.07 \mathrm{SE})$, and temporary emigration was also high $(0.77 \pm 0.06)$ and annually variable (range $0.34-0.97$ ). From egg shell remains of 124 hatched females, we observed 9 recaptures as nesting adults, suggesting that philopatry was also high (range 0.6-1.0). Given the relatively high rates of adult female breeding site fidelity and female philopatry that we estimated, management actions that reduce mortality of adult females and increase annual productivity are likely to help maintain the population of a few hundred breeding Steller's eiders on the Arctic Coastal Plain of Alaska.
\end{abstract}

KEY WORDS: Polysticta stelleri - Temporary and permanent emigration - Apparent survival · Capture probability $\cdot$ Nest detection

\section{INTRODUCTION}

Three breeding populations of Steller's eiders Polysticta stelleri are currently recognized: the RussianAtlantic, the Russian-Pacific, and the Alaska-breeding (USFWS 2002). The Russian-Atlantic population

${ }^{*}$ Corresponding author: david_safine@fws.gov winters in northern Europe and nests in western Arctic Russia, the Russian-Pacific population winters primarily in southwest Alaska and nests in eastern Arctic Russia, and the Alaska-breeding population winters in the same areas as the Russian-Pacific population, but nests in Alaska (USFWS 2002). The spe-

( ) MS Lindberg, AE Riddle, TE Hollmén, and outside the USA the US Government 2020. Open Access under Creative Commons by Attribution Licence. Use, distribution and reproduction are unrestricted. Authors and original publication must be credited. 
cies is listed as Vulnerable under the IUCN Red List (BirdLife International 2018). The Alaska-breeding population is listed as 'threatened' under the US Endangered Species Act because of a perceived contraction of the breeding range in North America (USFWS 1997). Alaska-breeding birds intermix with the larger population of Russian-Pacific birds at molting, staging, and wintering areas in southwest Alaska (Dau et al. 2000), and are called the 'Pacific population' for monitoring purposes.

Abundance of the Pacific population was indexed by annual aerial counts of eiders during spring migration in southwest Alaska from 1992-2012, and this index averaged 80000 individuals (USFWS unpubl. data). The Alaska-breeding birds comprise only a small fraction of the Pacific population, and were believed to be more widely distributed and abundant historically, although limited historical data exist to make comparisons with current information (USFWS 2002). The Alaska-breeding population is now restricted to the Arctic Coastal Plain (ACP) of northern Alaska (USFWS 2002, Amundson et al. 2019), and counts from annual spring surveys on the ACP averaged $~ 300$ birds between 2007 and 2017 (range 68-745; USFWS unpubl. data). A subpopulation breeding on the Yukon-Kuskokwim Delta (YKD) of Alaska is considered nearly extirpated, with only an occasional nest discovered there in some years (Kertell 1991, Flint \& Herzog 1999, USFWS unpubl. data).

Since the Alaska-breeding population was listed as threatened in 1997, the US Fish and Wildlife Service has worked with partners to plan and implement actions that contribute to recovery of the Alaskabreeding population, such as increasing the size of both the ACP and YKD breeding subpopulations. Because Alaska-breeding birds intermix with the Russian-Pacific population in southwest Alaska, an exchange of birds between breeding areas is likely to occur (USFWS 1997, Dunham \& Grand 2017), resulting in limited genetic differentiation between breeding populations (Pearce et al. 2005). However, little is known about the rates of return to breeding areas by adult females and natal areas by juvenile female Steller's eiders. Return rates to breeding and natal areas are critical pieces of information when developing and prioritizing management actions for subpopulation increase, such as predator control. Given the importance of understanding fidelity and emigration and immigration rates to population growth for small populations at the edge of a species' range (such as the Alaska-breeding population), an understanding of dispersal and fidelity patterns is required to evaluate population viability and craft effective management actions. For example, recent management actions have targeted both productivity and survival of Alaska-breeding Steller's eiders by reducing nest predator populations in the highest-density nesting area, and outreach and education to reduce shooting of adults and ingestion of spent lead shot (USFWS 2002). However, the effect of increasing adult survival or productivity on population growth rate depends on the proportion of adults and/or juveniles that return to breed in the population of management interest.

The objective of this study was to investigate female breeding site fidelity (the probability that adult females return annually to a previous nesting area, regardless of natal origin) and female natal site fidelity (hereafter, philopatry: the probability that a female returns to her natal site to nest; Pearce 2007) of Steller's eiders in Alaska. The small size of breeding subpopulations of Steller's eiders in Alaska and the high annual variation in breeding effort by this species (Quakenbush et al. 2004) led to the need for a genetic mark-recapture approach for quantifying annual demographic parameters associated with adult and juvenile return rates to breeding areas. Here, we focus on the ACP subpopulation of Steller's eiders near the community of Utqiagivik (formerly Barrow), Alaska, using a long-term (1995-2016) collection of nest materials (eggshell membranes and feathers) and blood samples as a 'marked' population (Pearce et al. 1997) from which to infer rates of fidelity and philopatry (Booms et al. 2011).

\section{MATERIALS AND METHODS}

\subsection{Study area}

We defined the study area as the combined area searched for nests in June and July of 1995-2016 near Utqiaǵvik, Alaska $\left(71^{\circ} 18^{\prime} \mathrm{N}, 156^{\circ} 40^{\prime} \mathrm{W}\right)$, located at the northwestern tip of the ACP (Fig. 1). The area consists of low-elevation tundra and poorly drained wetlands underlain with permafrost. Shallow lakes and lake basins, as well as ice-wedge polygons (both high and low-center) forming small ponds, are the main topography in the area. Emergent wetland vegetation is dominated by sedges Carex aquatilis and pendant grass Arctophila fulva. The weather is influenced by marine conditions. Brown lemming Lemmus trimucronatus populations fluctuate annually, but provide the primary source of summer food for avian and mammalian predators 


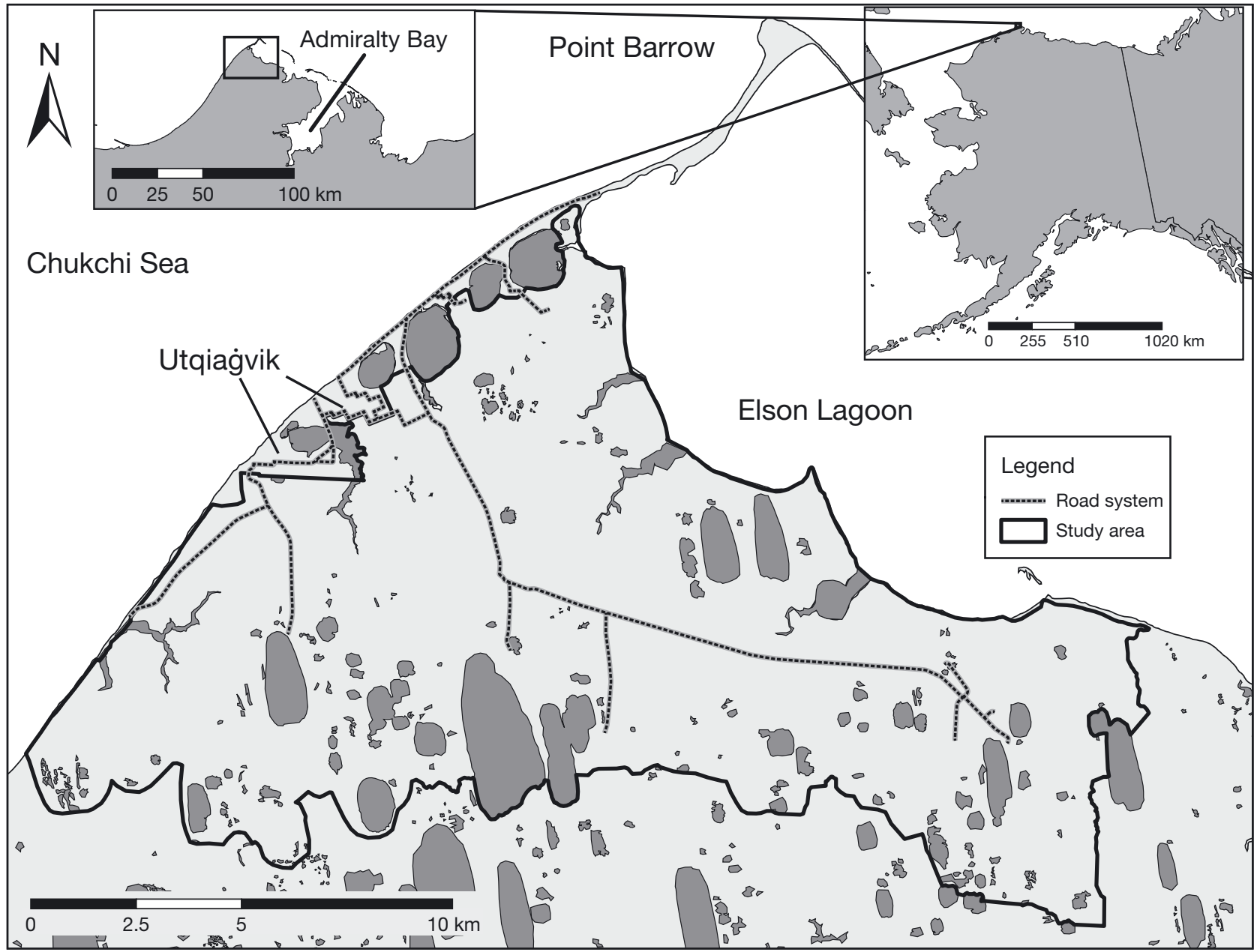

Fig. 1. Study area for Steller's eiders Polysticta stelleri near Utqiaġvik (formerly Barrow), Alaska, from 1995-2016. Darker gray shaded areas in the detail map represent bodies of water

when their numbers are high. Collared lemmings Dicrostonyx groenlandicus are present but in lower numbers. Common mammalian predators include Arctic fox Vulpes lagopus and least weasel Mustela nivalis. The avian community consists of groundnesting species of waterfowl, shorebirds, and passerines, as well as avian predators such as snowy owls Bubo scandiacus, pomarine jaegers Stercorarius pomarinus, parasitic jaegers $S$. parasiticus, and glaucous gulls Larus hyperboreus. Snowy owls and pomarine jaegers nest in the study area when lemmings are higher in abundance, while gulls and parasitic jaegers are present and nest annually. Owls, jaegers, gulls, and Arctic foxes prey on Steller's eider eggs (USFWS unpubl. data), and snowy owls have been identified as a source of adult female mortality (Quakenbush \& Suydam 1999).

Steller's eider density on the ACP increases northward towards the tip of Point Barrow and is densest near Utqiag்vik (Fig. 1). Steller's eiders have a short breeding season, arriving in late May or early June, and departing between July and September depending on sex and breeding success (Quakenbush et al. 2004).

\subsection{Nest searching and sample collection}

Nest searching was conducted using different methods from 1995-2016. Given the low density of nests and variable breeding effort, the objective of nest searching was primarily to maximize the sample size of nests, not to obtain a randomized or systematic sample of the study area. Thus, searches targeted areas with a higher probability of finding nests to maximize the recapture rate of females and precision of nest survival estimates. With the exception of 2004-2006, primary search areas included locations 
within $\sim 400 \mathrm{~m}$ of lone males, lone females, or pairs observed that year, and areas with higher nest densities in past years. Some areas were searched in multiple years, others in only 1 year (Fig. 2), and areas may have been searched more than once per year if we believed a nest was missed. We also recorded nests found incidentally by our crew or other researchers while walking in the study area. From 2004 to 2006, an adaptive cluster sampling method was used to estimate nest density in the study area. The variation in methods resulted in nest search areas that varied annually in location, size, and search effort.

Nest searching was mainly conducted by walking search areas between 09:00 and $1800 \mathrm{~h}$, Alaska Daylight Time, between $\sim 20$ June and 20 July. We used groups of 2-6 people, spread 5-10 m abreast, and visually searched to either side and ahead as we walked to completely cover the area. Nests were dis- covered by either flushing a hen, seeing a hen on a nest without flushing the bird, or finding an unattended nest (e.g. hen on a nest break, or a depredated or hatched nest). A nest was defined as a scrape or depression that contained sufficient down, contour feathers, or eggs to positively identify species. Contour feather samples from known nests and a photographic field guide (Bowman 2008) were used to aid in identification of nests and eggs. Nests were visited approximately every $7 \mathrm{~d}$ until nest fate was determined (hatched, destroyed, or abandoned). After hatching or nest failure, contour feathers and/ or egg membranes from the nest bowl were collected for genetic analysis. In some cases, we captured females during late incubation at the nest and collected a blood sample. Nest contour feathers and duckling egg membranes from nests were dried, labeled, and stored in paper envelopes at room temperature. Blood samples were collected from the

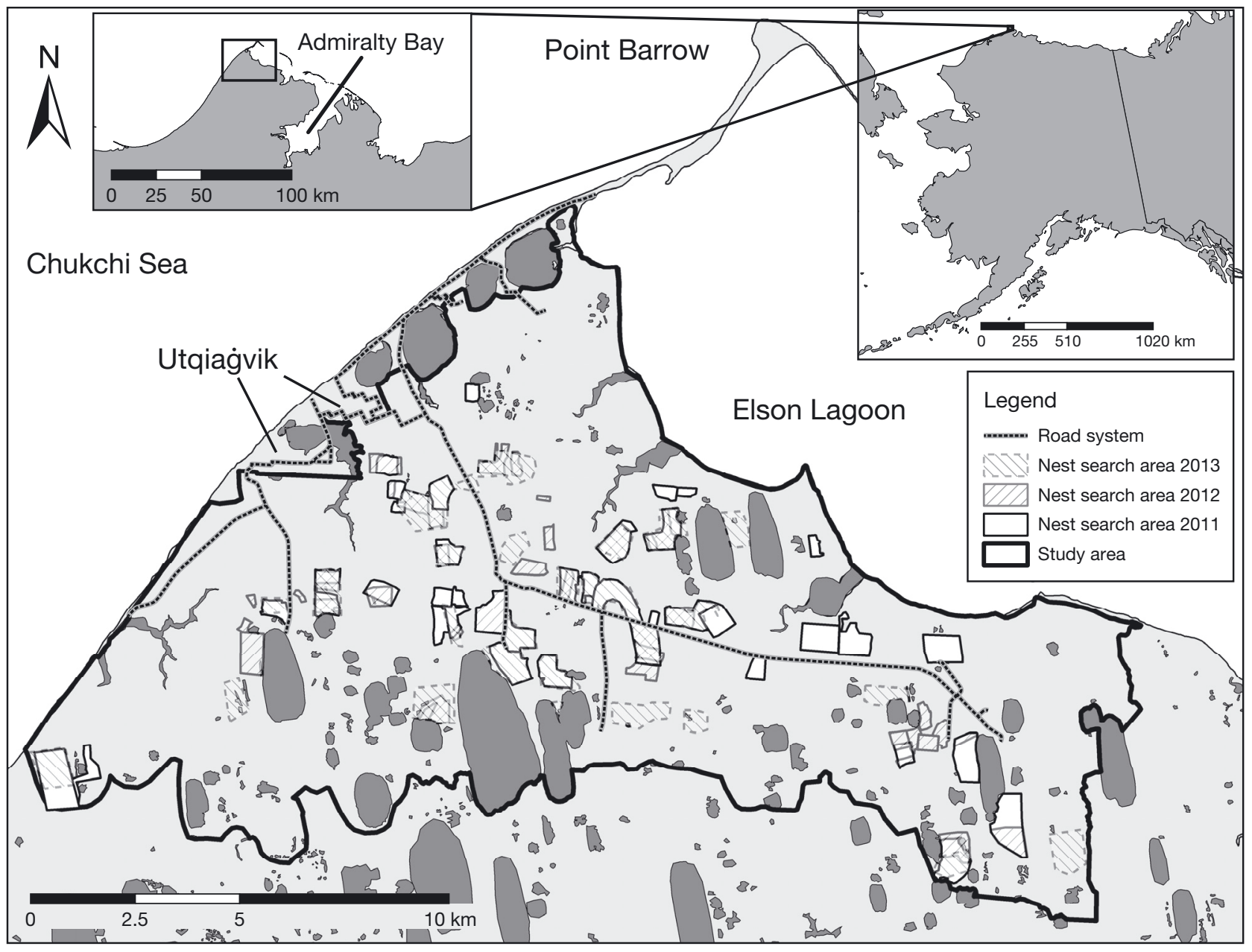

Fig. 2. Example of the location and extent of nest search areas for Steller's eiders Polysticta stelleri near Utqiagivik, Alaska, during 3 of the study years (2011-2013) 
brachial or jugular vein for individuals trapped on the study area and stored in blood preservation buffer (Longmire et al. 1988). Genotypes were primarily derived from nest contour feathers, although a blood sample was used if the hen had been captured but nest feathers were not collected from that nest.

\subsection{Laboratory methods and genetic analysis}

Detailed descriptions of marker selection, laboratory analysis procedures (genotyping and molecular sexing) and genetic data analyses are provided in the Supplement at www.int-res.com/articles/suppl/n041 p349_supp.pdf. In brief, genetic methods were used to document sex and identify individuals with a high degree of confidence, so that capture histories of individuals could be constructed.

\subsection{Mark-recapture analysis}

\subsubsection{Emigration}

We used several different data sources to estimate emigration by mostly following the modeling framework described by Lindberg et al. (2001). Specifically, we analyzed capture histories of genetically identified individuals using program MARK (White \& Burnham 1999) to estimate emigration.

Permanent emigration $\left(\hat{\alpha}_{i+1}\right)$ is defined as the probability that an individual associated with the available nesting population in year $i$ does not remain associated with the available nesting population in year $i+1$ given that the individual survives between year $i$ and year $i+1$. In this study, individuals were identified through genetic sampling of tissues at the nest site; therefore, an individual is associated with the available nesting population if it is nesting in the search area in any year following initial detection of that individual. That is, given nesting and detection in year $i$, and survival from year $i$ to year $i+n$ (i.e. the future), the individual has a non-zero probability of returning to nest in the search area in year $i+n$. The available nesting population in this analysis is eiders nesting in the area searched in any given year. The complement of permanent emigration $\left(1-\hat{\alpha}_{i+1}\right)$ is breeding site fidelity, defined as the probability that an individual associated with the available nesting population in year $i$ remains associated with the available nesting population in year $i+1$ given survival between year $i$ and year $i+1$. Temporary emigration $\left(\hat{\gamma}_{i}\right)$ is defined as the probability that an indi- vidual alive and associated with the available nesting population in year $i$ is not nesting in the search area in year $i$. Areas searched for nests were not randomly selected nor were they contiguous, and search effort varied annually; therefore, the search area and the definition of available nesting population varied annually (Fig. 2). We consider the effects of this spatial variation on estimates of emigration in the Discussion (Section 4).

We used Cormack-Jolly-Seber (CJS) models to estimate apparent survival and capture probability (Lebreton et al. 1992). Apparent survival probability $\left(\hat{\varphi}_{i}\right)$ is the probability that an individual alive and associated with the available nesting population in year $i$ survives and does not permanently emigrate between year $i$ and year $i+1$. Apparent capture probability $\left(\hat{p}_{a i}\right)$ is defined as the probability that an individual is nesting in the search area in year $i$ and is detected. This parameter is regarded as 'apparent' probability because an individual can be missed in year $i$ because they are present (nesting in the search area) and not detected or they are temporally absent (not nesting in the search area that year). Following the approach described by Lindberg et al. (1998), we estimated $\hat{\alpha}_{i}$ (permanent emigration) as:

$$
\hat{\alpha}_{i+1}=1-\frac{\hat{\varphi}_{i}}{\hat{S}_{i}}
$$

where true survival $\left(\hat{S}_{i}\right)$ is the probability that an individual alive in year $i$ survives to year $i+1$. We used the point estimate of annual survival probability from Frost et al. (2013; $0.86 \pm 0.03 \mathrm{SE})$, based on recaptures of molting adult female Steller's eiders at Izembek Lagoon, Alaska, 1993-2006, as $\hat{S}_{i}$ to estimate $\hat{\alpha}_{i+1}$. Although the estimate of Frost et al. (2013) includes some permanent emigration, it is probably minimal, at least at a local scale, because birds tend to show high rates of fidelity to molting lagoons $\left(>0.95\right.$, Flint et al. 2000). To estimate $\hat{\gamma}_{i}$ (temporary emigration), we needed to derive closed capture probability $\left(\hat{p}_{i}\right)$ or the probability that an individual nest is detected in year $i$ given that it is present in the search area. We first estimated the number of nests initiated in the search area in year $i\left(\hat{N}_{n i}\right)$ :

$$
\hat{N}_{n i}=\frac{N_{h i}}{\hat{S}_{n i}}
$$

where $N_{h i}$ is the number of nests that were observed to hatch from the nests that were initially found active in year $i$ (this excludes any nest initially found hatched) and $\hat{S}_{n i}$ is the probability that a nest survived to hatch at least 1 duckling in year $i$ (Miller \& Johnson 1978, Johnson \& Shaffer 1990). $\hat{S}_{n i}$ was esti- 
mated using the nest survival module in program MARK (White \& Burnham 1999) based on a $30 \mathrm{~d}$ exposure period (laying and incubation; Quakenbush et al. 2004). We estimated closed capture probability $\left(\hat{p}_{i}\right)$ as:

$$
\hat{p}_{i}=\frac{N_{f i}}{\hat{N}_{n i}}
$$

where $N_{f i}$ is the number of active nests found. We estimated $\hat{\gamma}_{i}$ (temporary emigration) as:

$$
\hat{\gamma}_{i}=1-\left(\frac{\hat{p}_{a i}}{\hat{p}_{i}}\right)
$$

When possible, we used the delta method to estimate sampling variance for all parameters (Seber 1982).

\subsubsection{Philopatry (natal site fidelity)}

Low sample sizes precluded using a modeling framework to estimate philopatry. Instead, we compared the results we observed (the number of female ducklings hatched from sampled egg membranes that were later detected as adult females on a nest at least once in the study area) to the number that would be expected given available vital rate estimates and natal philopatry of 1.0. The difference between observed and expected values provided an inference into the level of philopatry in Steller's eiders. To calculate the total number of expected recaptured nesting hens over the course of the study, we applied the following vital rates to the number of female ducklings genetically identified in a given year: duckling survival (0.44, USFWS unpubl. data; brood survival adjusted for brood size at fledge), first year survival (0.4 [Flint 2015] to 0.67 [Oppel \& Powell 2010; king eider Somateria spectabilis]), second year survival (0.75; Dunham \& Grand 2017), apparent annual survival (this study), apparent capture probability (constant and year-specific model results from this study). Given that first year survival estimates for Steller's eiders are based on surrogate species and expert opinion, we used a range of values from $0.4-0.67$ to calculate possible outcomes. We assumed all females would become capable of nesting at $2 \mathrm{yr}$ of age. Female Steller's eiders are thought to begin nesting at 2-3 yr of age (Fredrickson 2001), and the youngest age we detected a nesting hen in this study was 2 yr. Therefore, females hatched in the last and second to last study year (2015 and 2016) would have no chance of being detected in this study. Calculations were made for the cumulative total expected recaptures for each cohort of ducklings across study years, and then summed for all cohorts. For example, for female ducklings in the 2008 cohort, we summed the expected number of recaptured nesting hens for each year between 2010 and 2016, and considered that sum to be the expected total for the cohort.

\section{RESULTS}

\subsection{Nests and genetic analyses}

We found 365 nests from 1995-2016; no nests were found in 1998, 2001-2004, and 2009. The number of nests found per year ranged from $0-78$. We searched an average of $11 \mathrm{~km}^{2}$ per year (2005-2016 average; range $5-17 \mathrm{~km}^{2}$ ) in a study area of $\sim 170 \mathrm{~km}^{2}$.

We obtained genotypes in every year from 1995$2016\left(\mathrm{n}=2-47 \mathrm{yr}^{-1}\right)$, except 1997, 1998, 2001-2004, and 2009, when little to no nesting occurred near Utqiaġvik (USFWS unpubl. data). Steller's eider genotypes were derived from contour feathers $(\mathrm{n}=$ 217 nests) and blood ( $\mathrm{n}=7$ females). Of the 224 nests from which females were genetically identified, 200 unique individuals and 24 recapture events were detected. These 24 recapture events represented 19 individual females, as 3 females were recaptured at least twice. Average $( \pm \mathrm{SE})$ distance between recaptures (known nesting attempts) was $2.6 \pm 0.5 \mathrm{~km}$ (range $0.1-10 \mathrm{~km}$ ), and average time between known nesting attempts was $3.0 \pm 0.5 \mathrm{yr}$ (range 1-10 yr). Among all years and nests sampled, we recorded 3 instances (1 in 2011 and 2 in 2014) where the same individual hen was found at more than 1 nest site in the same year (i.e. a re-nesting attempt). We had no records of more than 1 female genotype in the same nest bowl in the same year (i.e. nest parasitism). To provide data accessibility, sample and microsatellite genotype data used in the analyses are available in Talbot et al. (2020).

\subsection{Emigration}

We adjusted interval lengths between years with samples to account for years without data and make estimates of survival comparable on an annual scale. We only considered 2 CJS models because of small sample sizes: a model with constant survival and capture probability $(\varphi() p.()$.$) , and a model with con-$ stant survival and year specific-capture probability $(\varphi() p.(t))$. AIC $_{\mathrm{c}}$ weights favored the model with constant parameters $(w(\varphi() p.())=0.69$.$) , and we used$ estimates from this model for our inferences about 
permanent and temporary emigration. We also considered the results of the year-specific capture probability model to examine variation in temporary emigration. Apparent survival probability (mean $\pm \mathrm{SE}$ ) was $0.78 \pm 0.06$ and capture probability was $0.06 \pm$ 0.02 . We used the estimate of annual survival probability from Frost et al. (2013) to derive an average estimate of permanent emigration $(\alpha=0.09 \pm 0.07)$ or its complement, breeding site fidelity $(0.91 \pm 0.07)$.

Using the estimate of apparent capture probability from the model with no year specificity $\left(p_{a}=0.06 \pm\right.$ $0.02)$ and an average estimate of closed capture probability $(p=0.63 \pm 0.01 ; 1995-2016, \mathrm{n}=14$ years with detection data), we estimated average temporary emigration as $0.90 \pm 0.03$. In the model with year-specificity, apparent capture probability was low and variable $(0.02-0.42 ; 2000-2016, \mathrm{n}=10$ years with estimate; Table 1 ). This suggests that temporary emigration is occurring and may also be variable. Therefore, we attempted to use year-specific estimates of capture probability to examine temporal patterns of temporary emigration. Data were only adequate to estimate $\gamma_{i}$ in 10 years: 2000, 2005, 2006, 2008, 2010-2012, 2014-2016 (Table 1). Temporary emigration was high in the years for which it could be estimated $(\geq 0.34)$ and the average probability of temporary emigration was $0.77 \pm 0.06$.

\subsection{Natal philopatry}

We collected 352 eggshell membranes from hatched nests in 9 years of the study: 2005-2008 and 2012-2016, and samples were screened for quality and gender. Genotypes generated from males, and females from 2015-2016, were removed, because no males were found to have left feathers in nests in the prior effort, and so the ability to recapture males was judged to be exceedingly low, and because the females from 2015-2016 had no chance of recapture by 2016 . The resulting sample included 124 females hatched that were available for recapture during the study. We observed (recaptured on a nest in the study area) 9 of the 124 females, and all 9 were from nests that hatched between 2005 and 2008. One female was detected returning and nesting in 2 years, and in 1 case, the daughter of a recaptured female returned to nest in the study area. The number of years between hatch and first nest detected in the study area averaged 6 yr (range $=2-11$ ). Distance between natal site and first detected nest averaged $5.1 \mathrm{~km}$ (range $=1.0-11.7 \mathrm{~km}$ ). Given the number of female egg shell membranes genetically identified each year, parameter estimates (see Section 2), temporary emigration rates from the constant capture probability model, and natal philopatry set at 1.0, we

Table 1. Data used to generate estimates of closed capture probability (nest detection rate) and temporary emigration for Steller's eiders Polysticta stelleri in the area searched for nests near Utqiagivik (formerly Barrow), Alaska, from 1995-2016. $\widehat{S}_{n i}$ : nest survival probability; $N_{f i}$ : number of active nests found; $N_{h i}$ : number of nests that hatched; $\widehat{N}_{n i}$ : number of nests initiated; $\widehat{p}_{i}$ : closed capture probability or nest detection rate; $\widehat{p}_{a i}$ : apparent capture probability; $\widehat{\gamma}_{i}$ : temporary emigration probability; na: not available; nd: no data

\begin{tabular}{|c|c|c|c|c|c|c|c|}
\hline Year & $\hat{S}_{n i}(\mathrm{SE})$ & $N_{f i}$ & $N_{h i}$ & $\hat{N}_{n i}(\mathrm{SE})$ & $\hat{p}_{i}(\mathrm{SE})$ & $\hat{p}_{a i}(\mathrm{SE})$ & $\hat{\gamma}_{i}(\mathrm{SE})$ \\
\hline 1995 & $0.19(0.08)$ & 22 & 8 & $42(0.68)$ & $0.52(0.01)$ & na & na \\
\hline 1996 & $0.53(0.19)$ & 9 & 6 & 11 (1.17) & $0.82(0.09)$ & na & na \\
\hline 1997 & na & 2 & 0 & na & na & na & na \\
\hline 1998 & nd & 0 & 0 & nd & nd & nd & nd \\
\hline 1999 & $0.10(0.05)$ & 24 & 5 & $51(0.26)$ & $0.47(0.00)$ & na & na \\
\hline 2000 & $0.14(0.09)$ & 14 & 4 & $29(0.35)$ & $0.48(0.01)$ & $0.06(0.06)$ & $0.88(0.13)$ \\
\hline 2001 & nd & 0 & 0 & nd & nd & nd & nd \\
\hline 2002 & nd & 0 & 0 & nd & nd & nd & nd \\
\hline 2003 & nd & 0 & 0 & nd & nd & nd & nd \\
\hline 2004 & nd & 0 & 0 & nd & nd & nd & nd \\
\hline 2005 & $0.31(0.15)$ & 12 & 6 & $19(0.89)$ & $0.63(0.03)$ & $0.42(0.28)$ & $0.34(0.45)$ \\
\hline 2006 & $0.88(0.12)$ & 16 & 15 & $17(1.73)$ & $0.94(0.10)$ & $0.14(0.10)$ & $0.85(0.10)$ \\
\hline 2007 & $0.47(0.16)$ & 12 & 7 & 15 (1.11) & $0.80(0.06)$ & na & na \\
\hline 2008 & $0.62(0.12)$ & 25 & 19 & $31(2.30)$ & $0.81(0.06)$ & $0.17(0.09)$ & $0.79(0.11)$ \\
\hline 2009 & nd & 0 & 0 & nd & nd & nd & nd \\
\hline 2010 & $0.29(0.36)$ & 2 & 1 & $3(0.36)$ & $0.67(0.08)$ & $0.04(0.04)$ & $0.94(0.06)$ \\
\hline 2011 & $0.50(0.14)$ & 20 & 14 & 28 (1.99) & $0.71(0.05)$ & $0.22(0.12)$ & $0.69(0.17)$ \\
\hline 2012 & $0.36(0.18)$ & 12 & 8 & $22(1.47)$ & $0.55(0.04)$ & $0.11(0.06)$ & $0.80(0.12)$ \\
\hline 2013 & na & 1 & 0 & na & na & na & na \\
\hline 2014 & $0.14(0.07)$ & 23 & 7 & $52(0.48)$ & $0.44(0.00)$ & $0.19(0.10)$ & $0.57(0.22)$ \\
\hline 2015 & $0.12(0.13)$ & 7 & 3 & $25(0.39)$ & $0.28(0.00)$ & $0.02(0.02)$ & $0.93(0.07)$ \\
\hline 2016 & $0.36(0.18)$ & 9 & 5 & $14(0.92)$ & $0.64(0.04)$ & $0.02(0.02)$ & $0.97(0.03)$ \\
\hline
\end{tabular}


would expect to recapture a cumulative total of between 4.3 and 7.1 (range due to first year survival) females on the nest from a sample of 124 ducklings. Given the same parameter estimates, temporary emigration rates from the year-specific capture probability model, and philopatry set at 1.0, we would expect to recapture a cumulative total of between 9.8 and 16.4 (range due to first year survival) females on the nest. Our observed outcome (9) was in between the expected outcomes from the 2 models.

\section{DISCUSSION}

\subsection{Nests and genetic analyses}

The number of nests found per year was variable and relatively low, due to species life history traits such as large annual differences in nesting effort and success, and lower nesting density. In addition, there were changes in staff, search areas, and methods over the duration of the study ( $22 \mathrm{yr}$ ) that likely affected annual nest detection probability. Despite these challenges, we found a sufficient sample of nests to examine spatial and temporal patterns of philopatry and breeding site fidelity for female Alaska-breeding Steller's eiders. Had we relied solely on traditional mark-recapture methods (i.e. marking hens on the nest during late incubation with bands or nasal markers, then resighting in subsequent years), the sample size would have been much smaller, and reasonably precise estimates would not have been feasible.

Our observation of 3 re-nesting attempts demonstrates that Steller's eiders are capable of re-nesting, but it occurs rarely. This was expected because Steller's eiders initiate nests later than most waterfowl species near Utqiagivik (USFWS unpubl. data), and the short growing season of the Arctic constrains the success of replacement clutches laid late in the season.

\subsection{Permanent emigration and survival}

Our estimate of low permanent emigration suggests that female Steller's eiders are likely to remain in the population and nest in the study area in multiple years. Our estimate of female breeding site fidelity (the converse of permanent emigration; 0.91) is similar to estimates for other species of waterfowl such as brant Branta bernicla (0.9, Lindberg et al. 1998; 1.0, Sedinger et al. 2008), tufted ducks Aythya fuligula and pochards A. ferina (near 1.0, Blums et al.
2002), hooded mergansers Lophodytes cucullatus (0.92, Pearce et al. 2008), and king eiders (1.0, Phillips \& Powell 2006). It is also consistent with observations of high female return rates to breeding areas in canvasbacks A. valisineria (Anderson et al. 1992), common eiders Somateria mollissima (Goudie et al. 2000), and other sea ducks (Eadie \& Savard 2015). However, direct comparisons between studies are difficult because measures of breeding site fidelity are affected by size of the study area and breeding propensity of the species.

Despite the consistency with emigration rates of other waterfowl species, our results are somewhat surprising because of the hypothesized association of Steller's eiders with 2 nomadic migrant species: snowy owls and pomarine jaegers (Solovyeva 1999, Quakenbush et al. 2004). The number of Steller's eider nests near Utqiagivik appears correlated with the presence of nesting pomarine jaegers and snowy owls, which only occur in years with high brown lemming abundance (Quakenbush \& Suydam 1999, Quakenbush et al. 2004, USFWS unpubl. data). Nesting near jaegers and owls, which typically exhibit aggressive nest defense behavior, may provide protection for Steller's eiders from foxes (Quakenbush et al. 2004). If successful nesting is highly dependent on this relationship, one would predict that pre-breeding Steller's eiders prospect over a wide area (ACP or even both Alaska and Russia) searching for ideal conditions prior to nest initiation, rather than exhibiting high site fidelity to specific nesting areas. However, the low estimate of permanent emigration suggests that Steller's eiders are site-faithful, but may exhibit annually variable breeding propensity, in which some or most of the population opts not to nest in some years.

Apparent annual survival probability of nesting females in this study $(0.78)$ is high compared to dabbling and diving duck species (Johnson et al. 1992) but similar to other arctic and subarctic nesting sea ducks (Wilson et al. 2007, Oppel \& Powell 2010, Milton et al. 2016, Solovyeva et al. 2017). Apparent survival probability is lower than true survival probability, because the CJS model assumes that all females remain in the population (i.e. no permanent emigration); therefore, true survival is likely higher than apparent survival. Our result, derived directly from data on marked Steller's eiders nesting on the ACP, is higher than 0.75 estimated by Dunham \& Grand (2017) for female Steller's eiders using a Bayesian state-space model framework to estimate demographic parameters that most likely describe aerial survey data. 


\subsection{Temporary emigration}

Estimates of temporary emigration were high regardless of the model used. We used active nests to estimate closed capture probability (nest detection) because active nests contribute to the calculation of daily nest survival rate, which requires known dates of initiation and failure. However, we also found inactive nests (those that failed or hatched prior to discovery). If inactive nests were included in the calculation, the detection rate and resulting temporary emigration estimate would be even higher than reported here.

We suggest 2 potential explanations for the pattern of high temporary emigration of Steller's eiders in our study area. First, temporary emigrants may forgo nesting in some years when breeding conditions are unfavorable, thus being unavailable for detection in our study (as in common eiders; Coulson 2010); the number of nests found in our Utqiagivik study area is highly variable (range 0-78, 1991-2018, USFWS unpubl. data), suggesting that Steller's eiders commonly employ this strategy. Solovyeva (1999) also observed high variation in annual nest numbers of Steller's eiders at a Lena River Delta study site in Arctic Russia. The strategy of choosing to forgo nesting in years when conditions are unfavorable is consistent with other K-selected traits of Steller's eiders, such as relatively high annual adult survival (0.86, Frost et al. 2013; this study). Breeding propensity could be affected by a number of factors, including annual changes in the composition of the ecological community at the breeding area (i.e. abundance of lemmings, pomarine jaegers, and/or snowy owls; Quakenbush et al. 2004) and conditions in marine non-breeding areas (Alisauskas \& Ankney 1992, Petersen \& Douglas 2004, Coulson 2010, Flint 2013).

An alternative explanation for high temporary emigration is that individuals are annually nesting, but outside of the annual search areas in years when they are undetected. These birds may be nesting within the study area near Utqiagivik, elsewhere on the $\mathrm{ACP}$, or in Russia. Females nesting within the study area, but outside the search area, account for at least some proportion of the temporary emigrants. Annually, we search a maximum of approximately $10 \%$ of the $134 \mathrm{~km}^{2}$ study area (Fig. 2). However, this does not mean we miss $90 \%$ of the nesting hens in the study area each year, as the areas in which we conduct nest searches are not selected randomly. Rather, they are based on the presence of breeding pairs observed earlier in the season and on traditionally used nesting areas. In addition, nests found oppor- tunistically by other researchers are also included. As an alternative, we considered a secondary method to estimate the portion of nests detected in our study area by using the number of male Steller's eiders counted during breeding pair surveys in the study area. If each male was paired and represented a female, this count would indicate the maximum potential number of nests that could be initiated in the study area. Thus, the observed number of nests found in the study area divided by the potential number of nests available to be detected (i.e. number of males) would provide a rough estimate of the annual nest detection rate. Using this metric, we found that in years when at least 1 nest was found, nest detection rate for the study area averaged 32\% (19992016; USFWS unpubl. data). Because some male Steller's eiders are not paired, and of those that are paired, not all hens initiate a nest in the study area, this estimate should be viewed as a minimum estimate of nest detection for our study area. Therefore, we believe that the annual nest detection rate for the entire study area is at least $32 \%$, but well below $100 \%$, indicating that some proportion of the temporary emigrants are females nesting within the study area but outside annual search areas.

In addition to failing to detect Steller's eiders because they nested within the study area but outside annual search areas, females may also opt to nest outside of the study area but within other parts of the ACP. The considerable distance between individual Steller's eider nesting attempts (average $2.6 \mathrm{~km}$ ) supports both of these possibilities. We note that the distance between nesting attempts is likely biased low as these are known nests found strictly in the study area, and any potential nesting outside this area had no potential to be detected. Our estimate of distance between nesting sites of Steller's eiders is comparable to ACP-nesting king eiders (average $3.9 \mathrm{~km}$, range 0.6-14.6 km; Phillips \& Powell 2006), but larger than king eiders nesting near Karrak Lake in the Northwest Territories, Canada (females with successful first nest $=0.2 \mathrm{~km}$, unsuccessful $=0.6 \mathrm{~km}$, with the largest distance moved of 2.8 km; Kellett 1999), and common eiders in the Baltic Sea (median $=21 \mathrm{~m}$, range $1 \mathrm{~m}-2.9 \mathrm{~km}$; Ost et al. 2011). Also, dispersing far from previous nesting sites may be expected if Steller's eiders evaluate nest sites based on the proximity of other nesting birds (Quakenbush et al. 2004) or other factors that vary considerably across the landscape from year to year.

Lastly, temporary emigrants may possibly nest in Russia in years they are not detected in Alaska. Rosenberg et al. (2014) collected 3 yr (2004-2006) of 
movement data from 16 adult females and 1 secondyear female marked with satellite transmitters near Kodiak Island, Alaska. One female was classified as a breeder in 2 consecutive years based on the amount of time spent at inland locations, which were approximately $290 \mathrm{~km}$ apart in Russia, suggesting that large distances between successive annual nesting attempts are possible. Martin et al. (2015) implanted 6 females with satellite transmitters near Utqiagivik during the breeding seasons of 2000 and 2001. Only 1 female survived to a subsequent breeding season, and in early June of 2002, she was located in Peard Bay, just to the west of Utqiagivik, before the transmitter failed. Because no Steller's eider nests were recorded in our study area in 2002 (USFWS unpubl. data), but the bird was located in northern Alaska, this provides evidence against nesting in Russia when females are not detected. To date, there is no evidence of an individual bird nesting in both continents in its lifetime, but large-scale movements among years within a continent may be occurring. It is important to note that these 2 explanations for temporary emigration (non-breeding and nesting outside the search area) are not mutually exclusive, as an individual may fall into both categories over time.

\subsection{Philopatry}

The number of nesting females recaptured near their natal site was unexpected given the sample size, the rate of temporary emigration, and the potential for first year survival to be relatively low in Steller's eiders. Assuming philopatry of 1.0, the number of nesting females expected to be recaptured ranged from 4 to 16 ; we recaptured 9 hens, in the middle of this range. Under the constant capture probability model, the actual number of recaptures exceeded the entire range in expected values, supporting the potential that philopatry is 1.0 . Under the year-specific capture probability model, 9 observed recaptures indicate that philopatry could range from about 0.6 to 0.9 . Given the uncertainty in vital rates, especially first year survival, and the likelihood that capture probability varies annually, these results provide rough brackets around levels of philopatry for Alaska-breeding Steller's eiders of 0.6 to 1.0. In a qualitative sense, female Steller's eiders appear very likely to return to their natal areas for nesting.

Few estimates of philopatry exist for waterfowl. Philopatry in common eiders has been estimated at 0.98 (Goudie et al. 2000), and brant averaged 0.83 (range 0.70-0.96, Sedinger et al. 2008); however, both species are known to nest colonially, which limits comparability to Steller's eiders. A study of king eiders on the ACP showed that 8 of $9(88 \%) 2 \mathrm{yr}$ old females returned to the tundra within $25 \mathrm{~km}$ of the lake where they were captured as ducklings (Oppel $\&$ Powell 2010). None of these king eider females appeared to nest that summer, but these data suggest that king eiders have high rates of philopatry (Oppel \& Powell 2010). However, Pearce et al. (2004) found no genetic signal of philopatry in king eiders.

Despite behavioral evidence of high philopatry and breeding site fidelity for Steller's eiders in our study area, a population genetic analysis by Pearce et al. (2005) found limited differentiation in nuclear or mitochondrial DNA between Russia- and Alaskabreeding Steller's eiders. This result could mean: (1) female and/or male gene flow between the 2 locales is sufficient to prevent genetic differentiation (e.g. if all females were philopatric, levels of genetic differentiation between hens at each breeding area would be greater than observed); or (2) divergence of Russia- and Alaska-breeding populations occurred so recently that insufficient time has elapsed for genetic differentiation to occur. Our use of biparentally transmitted genetic markers made it difficult to disentangle sex-biased gene flow and thus corroborate our observation of female philopatry. New genomic approaches are currently underway to estimate gene flow and population definition in Steller's eiders of Alaska and Russia. Given that we can only estimate a range of philopatry (0.6-1.0), and values within that range would allow for ample gene flow, either explanation, or both, may explain the lack of genetic differentiation in Steller's eiders. Similar results have been found in other species; for example, female breeding site fidelity of hooded mergansers was estimated at approximately 0.92 from mark-recapture data, but genetic analysis revealed gene flow across portions of the species' range (Pearce et al. 2008). In harlequin ducks Histrionicus histrionicus, conservation-relevant demographic structuring was found at nonbreeding sites in the absence of genetic differentiation (Iverson et al. 2004, Esler et al. 2006).

\subsection{Management implications}

The results of this study suggest that Steller's eiders nesting near Utqiagivik, Alaska, have high adult female breeding site fidelity, and their female offspring are likely to return to their natal site to nest. Having estimates of these 2 demographic parameters facilitates modeling of population viability and plan- 
ning recovery actions. High breeding site fidelity indicates that protecting adult females from sources of mortality is important, as they are likely to return to nest in Alaska. Management actions that reduce acute (e.g. power line strikes) and chronic (e.g. lead exposure) sources of mortality are likely to help maintain a population of breeding Steller's eiders on the ACP of Alaska. Indications of high levels of philopatry suggest that management actions focused on increasing breeding productivity (e.g. predator control) are likely to yield increased recruitment into this breeding population. However, given their high levels of temporary emigration, the potential association of absence with low breeding propensity, and relatively K-selected life history traits (i.e. lower reproductive output), returns on investments into management actions for this listed population may be reduced.

Acknowledgements. We greatly appreciate the help provided by the long list of individuals who assisted with various aspects of the eider project from 1995-2016. We received tremendous assistance from the following USFWS staff: L. Quakenbush, P. Martin, T. Obritschkewich, M. Johnson, N. Rojek, J. Bennett, N. Graff, M. Wilson, S. Yannuzzi, M. Miller, N. Docken, M. Zarzycki, S. McDowell, K. Ott, M. Berger, E. Ahgeak, E. Nageak, S. Torrence, D. Walther, C. Latty, L. Snoddy, S. Hawks, M. Kuter, R. Howard, K. Laing, J. Eden, S. Jahrsdoerfer, J. Jenkins, A. Matz, N. Pamerin, D. Bachman, J. Priday, D. Rudis, J. Zelenak, B. Lake, L. Devaney, K. Russell, N. Adams, K. Weller, C. Donaldson, S. Speckman, L. Ziemba, F. Hannan, M. Korte, K. Fluetsch, and L. Thomas. USFWS volunteers (too numerous to list) donate their time and energy to this project each year, and we would not be able to conduct a project of this scale without their valuable assistance. Eider Journey students are a very important and enthusiastic part of the team; we thank the numerous Barrow High School students who have helped on the project since 1999. We appreciate the help of R. Lanctot and the USFWS shorebird crew, M. Pratt and the US Department of Agriculture's Wildlife Services Arctic fox trapping crew, and D. Holt of the Owl Research Institute for providing us with eider nest locations. We thank B. Pierson for database management. We value all the logistical assistance and support provided by staff at the North Slope Borough Department of Wildlife Management, particularly B. Nageak, C. Brower, T. Hepa, R. Suydam, T. Sformo, and B. Person. Thanks to the North Slope Borough School District for their generous inkind support and facilitating the participation of Barrow High School students in our work. We thank the people of Utqiag vik for making us feel welcome in their community, and Ukpeag vik Iñupiat Corporation, Inc. (UIC) for providing housing and allowing us to study eiders on their land. Thanks to the National Oceanic and Atmospheric Administration and the Climate Monitoring and Diagnostic Laboratory (NOAA/ CMDL) for access to NOAA/CMDL and US Geological Survey land. We appreciate the generous support and guidance of P. Sousa, D. Rocque, S. Conn, and J. Fox of USFWS Fairbanks Fish and Wildlife Field Office. The National Fish and Wildlife Foundation, US Bureau of Land Management, USFWS, Conoco Philips Alaska, Inc., and the North Slope Borough all provided critical project funding and in-kind support. Previous drafts of this manuscript were greatly improved by the reviews of D. Esler and 2 anonymous reviewers. Any use of trade, firm, or product names is for descriptive purposes only and does not imply endorsement by the US Government.

\section{LITERATURE CITED}

Alisauskas RT, Ankney CD (1992) Egg laying and nutrient reserves. In: Batt $\mathrm{BJD}$, Afton $\mathrm{AD}$, Anderson MG, Ankney CD, Johnson DH, Kadlec JA, Krapu GL (eds) Ecology and management of breeding waterfowl. University of Minnesota Press, Minneapolis, MN, p 30-61

Amundson CL, Flint PL, Stehn RA, Platte RM, Wilson HM, Larned WW, Fischer JB (2019) Spatio-temporal population change of Arctic-breeding waterbirds on the Arctic Coastal Plain of Alaska. Avian Conserv Ecol 14:18

Anderson MG, Rhymer JM, Rohwer FC (1992) Philopatry, dispersal, and the genetic structure of waterfowl populations. In: Batt BJD, Afton AD, Anderson MG, Ankney CD, Johnson DH, Kadlec JA, Krapu GL (eds) Ecology and management of breeding waterfowl. University of Minnesota Press, Minneapolis, MN, p 365-395

BirdLife International (2018) Polysticta stelleri. The IUCN Red List of Threatened Species 2018: e.T22680415A132 527232 (accessed 14 June 2019)

* Blums P, Nichols JD, Hines JE, Mednis A (2002) Sources of variation in survival and breeding site fidelity in three species of European ducks. J Anim Ecol 71:438-450

* Booms T, Talbot SL, Sage GK, McCaffery BJ, McCracken KG, Schempf PF (2011) Direct and indirect estimates of gyrfalcon nest site fidelity and breeding and natal dispersal using non-invasive genetic sampling. Condor 113: 768-778

Bowman TD (2008) Field guide to bird nests and eggs of Alaska's coastal tundra, $2^{\text {nd }}$ edn. Alaska Sea Grant College Program, University of Alaska Fairbanks, Fairbanks, AK

* Coulson JC (2010) A long-term study of the population dynamics of common eiders Somateria mollissima: Why do several parameters fluctuate markedly? Bird Study 57:1-18

*Dau CP, Flint PL, Petersen MR (2000) Distribution of recoveries of Steller's eiders banded on the Lower Alaska Peninsula, Alaska. J Field Ornithol 71:541-548

* Dunham K, Grand JB (2017) Evaluating models of population process in a threatened population of Steller's eiders: a retrospective approach. Ecosphere 8:e01720

Eadie JM, Savard JPL (2015) Breeding systems, spacing behavior, and reproductive behavior of sea ducks. In: Savard JPL, Derksen DV, Esler D, Eadie JM (eds) Ecology and conservation of North American sea ducks. Studies in Avian Biology 46. CRC Press, Boca Raton, FL, p 365-416

Esler D, Iverson SA, Rizzolo DJ (2006) Genetic and demographic criteria for defining population units for conservation: the value of clear messages. Condor 108:480-483

Flint PL (2013) Changes in size and trends of North American sea duck populations associated with North Pacific oceanic regime shifts. Mar Biol 160:59-65

Flint PL (2015) Population dynamics of sea ducks: using models to understand the causes, consequences, evolution, and management of variation in life history characteristics. In: Savard JPL, Derksen DV, Esler D, Eadie JM (eds) Ecology and conservation of North American sea ducks. Studies in Avian Biology 46, CRC Press, Boca Raton, FL, p 63-96 
Flint PL, Herzog MP (1999) Breeding of Steller's eiders, Polysticta stelleri, on the Yukon-Kuskokwim Delta, Alaska. Can Field Nat 113:306-308

Flint PL, Petersen MR, Dau CP, Hines JE, Nichols JD (2000) Annual survival and site fidelity of Steller's eiders molting along the Alaska Peninsula. J Wildl Manag 64:261-268

Fredrickson LH (2001) Steller's eider (Polysticta stelleri). In: Poole AF, Gill FB (eds) The birds of North America, No. 571. Cornell Lab of Ornithology, Ithaca, NY

Frost CJ, Hollmén TE, Reynolds JH (2013) Trends in annual survival of Steller's eiders molting at Izembek Lagoon on the Alaska Peninsula, 1993-2006. Arctic 66:173-178

* Goudie RI, Robertson GJ, Reed A (2000) Common eider (Somateria mollissima). In: Poole A, Gill F (eds) The birds of North America, No. 546. Lab of Ornithology, Ithaca, NY

Iverson SA, Esler D, Rizzolo DJ (2004) Winter philopatry of harlequin ducks in Prince William Sound, Alaska. Condor 106:711-715

Johnson DH, Shaffer TL (1990) Estimating nest success: when Mayfield wins. Auk 107:595-600

Johnson DH, Nichols JD, Schwartz MD (1992) Population dynamics of breeding waterfowl. In: Batt BJD, Afton AD, Anderson MG, Ankney CD, Johnson DH, Kadlec JA, Krapu GL (eds) Ecology and management of breeding waterfowl. University of Minnesota Press, Minneapolis, MN, p 446-485

Kellett DK (1999) Causes and consequences of variation in nest success of king eiders (Somateria spectabilis) at Karrak Lake, Northwest Territories. MSc thesis, University of Saskatchewan, Saskatoon

Kertell K (1991) Disappearance of the Steller's eider from the Yukon-Kuskokwim Delta, Alaska. Arctic 44:177-187

Lebreton JD, Burnham KP, Clobert J, Anderson DR (1992) Modeling survival and testing biological hypotheses using marked animals: a unified approach with case studies. Ecol Monogr 62:67-118

Lindberg MS, Sedinger JS, Derksen DV, Rockwell RF (1998) Natal and breeding philopatry in a black brant, Branta bernicula nigricans, metapopulation. Ecology 79: 1893-1904

Lindberg MS, Kendall WL, Hines JE, Anderson MG (2001) Combining band recovery data and Pollock's robust design to model temporary and permanent emigration. Biometrics 57:273-281

Longmire JL, Lewis AK, Brown NC, Buckingham JM and others (1988) Isolation and molecular characterization of a highly polymorphic centromeric repeat in the family Falconidae. Genomics 2:14-24

Martin PD, Douglas DC, Obritschkewitsch T, Torrance S (2015) Distribution and movements of Alaska-breeding Steller's eiders in the non-breeding period. Condor 117: 341-353

Miller HW, Johnson DH (1978) Interpreting the results of nesting studies. J Wildl Manag 42:471-478

Milton GR, Iverson SA, Smith PA, Tomlik MD, Parsons GJ, Mallory JL (2016) Sex-specific survival of adult common eiders in Nova Scotia, Canada. J Wildl Manag 80: 1427-1436

Oppel S, Powell AN (2010) Age-specific survival estimates of king eiders derived from satellite telemetry. Condor 112:323-330

Ost M, Lehikoinen A, Jaatinen K, Kilpi M (2011) Causes and consequences of fine-scale breeding dispersal in a female-philopatric species. Oecologia 166:327-336

Pearce JM (2007) Philopatry: a return to origins. Auk 124: 1085-1087
Pearce JM, Fields RL, Scribner KT (1997) Nest materials as a source of genetic data for avian ecological studies. J Field Ornithol 68:471-481

Pearce JM, Talbot SL, Pierson B, Peterson MR, Scribner KT, Dickson LD, Mosbech A (2004) Lack of spatial genetic structure among nesting and wintering king eiders. Condor 106:229-240

* Pearce JM, Talbot SL, Peterson MR, Rearick JR (2005) Limited genetic differentiation among breeding, molting and wintering groups of the threatened Steller's eider: the role of historical and contemporary factors. Conserv Genet 6:743-757

Pearce JM, Blums P, Lindberg MS (2008) Site fidelity is an inconsistent determinant of population structure in the hooded merganser (Lophodytes cucullatus): evidence from genetic, mark-recapture, and comparative data. Auk 125:711-722

*Petersen MR, Douglas DC (2004) Winter ecology of spectacled eiders: environmental characteristics and population change. Condor 106:79-94

* Phillips LM, Powell AN (2006) Evidence for wing molt and breeding site fidelity in king eiders. Waterbirds 29: 148-153

Quakenbush L, Suydam R (1999) Periodic nonbreeding of Steller's eiders near Barrow, Alaska, with speculations on possible causes. In: Goudie RI, Petersen MR, Robertson GJ (eds) Behavior and ecology of sea ducks. Occas Pap 100. Canadian Wildlife Service, Ottawa, p 34-40

Quakenbush LT, Suydam RH, Obritschkewitsch T, Deering M (2004) Breeding biology of Steller's eiders (Polysticta stelleri) near Barrow, Alaska, 1991-1999. Arctic 57: 166-182

Rosenberg DH, Petrula MJ, Schamber JL, Zwiefelhofer D, Hollmén TE, Hill DD (2014) Seasonal movements and distribution of Steller's eiders wintering at Kodiak Island, Alaska. Arctic 67:347-359

Seber GAF (1982) The estimation of animal abundance and related parameters. Macmillan Publishing, New York, NY

* Sedinger JS, Chelgren ND, Ward DH, Lindberg MS (2008) Fidelity and breeding probability related to population density and individual quality in black brent geese Branta bernicula nigricans. J Anim Ecol 77:702-712

Solovyeva DV (1999) Biology and bioenergetics of the Steller's eider (Polysticta stelleri). PhD dissertation, Russian Academy of Sciences Zoological Institute, St. Petersburg

* Solovyeva DV, Kokhanova VY, Gabrielson M, Christie KS (2017) Testing for geographic variation in survival of spectacled eider populations in Chukotka, Russia and the Yukon-Kuskokwim Delta, Alaska. Arctic 70:287-294

Talbot SL, Sage GK, Fales K, Pierson, BJ (2020) Genetic data from nesting Steller's Eiders (Polysticta stelleri), near Utqiagivik, Alaska, 1995-2016. U.S. Geological Survey data release, https://doi.org/10.5066/P967DZ5L

USFWS (US Fish and Wildlife Service) (1997) Final Rule: Endangered and threatened wildlife and plants; Threatened status for the Alaska breeding population of the Steller's eider. Fed Regist 62:31748-31757

USFWS (2002) Steller's eider recovery plan. USFWS, Fairbanks, AK

White GC, Burnham KP (1999) Program MARK: survival estimation from populations of marked animals. Bird Study 46:S120-S139

Wilson HM, Flint PL, Moran CL, Powell AN (2007) Survival of breeding Pacific common eiders on the YukonKuskokwim Delta, Alaska. J Wildl Manag 71:403-410 